\title{
PENERAPAN MODEL MAKE A MATCH BERBANTUAN BIOCARD TERHADAP HASIL BELAJAR DAN KETERAMPILAN ARGUMENTASI SISWA
}

\author{
Amelia Purwaningsih ${ }^{1}$, Laili Fitri Yeni ${ }^{2}$, Titin $^{3}$ \\ ${ }^{1,2,3}$ Program Studi Pendidikan Biologi Fakultas Keguruan dan Ilmu Pendidikan Universitas \\ Tanjungpura, Jalan Prof. Dr. Hadari Nawawi, Pontianak \\ ${ }^{1}$ e-mail: amelia98purwaningsih@gmail.com
}

\begin{abstract}
Abstrak
Penelitian bertujuan untuk mengetahui penerapan model pembelajaran Make A Match berbantuan Biocard terhadap hasil belajar dan keterampilan argumentasi siswa pada materi Klasifikasi Makhluk Hidup kelas VII SMP Kemala Bhayangkari. Bentuk penelitian adalah Quasy Experimental Design dengan rancangan penelitian Nonequivalent Control Group Design. Sampel penelitian terdiri dari 2 kelas, yaitu kelas VII B sebagai kelas kontrol dan VII C sebagai kelas eksperimen. Teknik pengumpulan data menggunakan soal tes. Analisis data menggunakan Effect Size. Hasil penelitian menunjukkan skor rata-rata hasil belajar kelas eksperimen sebesar 16,04 sedangkan pada kelas kontrol 13,74. Hal ini menunjukkan model make a match berbantuan biocard memiliki pengaruh signifikan terhadap hasil belajar siswa. Keterampilan argumentasi pada penelitian ini menggunakan argumentasi Toulmin yaitu menilai aspek data,claim,warrant dan backing. Hasil penelitian keterampilan argumentasi kelas eksperimen menunjukkan kriteria baik (70,82\%), sedangkan pada kelas kontrol dengan kriteria cukup $(68,40 \%)$. Dapat disimpulkan model make a match berbantuan biocard berpengaruh terhadap keterampilan argumentasi siswa.
\end{abstract}

Kata Kunci: hasil belajar, keterampilan argumentasi, make a match.

\begin{abstract}
The research aimed to determine the application of the Biocard-aided Make A Match learning model to the learning outcomes and students' argumentation skills in the Classification of Living Class VII material of Kemala Bhayangkari Middle School. The form of research was Quasy Experimental Design with Nonequivalent Control Group Design research design. The research sample consisted of 2 classes, VII $B$ as a control class and VII $C$ as an experimental class. Data collection techniques used test questions. Data analysis used Effect Size. The results showed the average score of the experimental class learning outcomes was 16.04 while that of the control class was 13.74. This shows the biocard-aided make a match model has a significant influence on student learning outcomes. Argumentation skills in this study use Toulmin's argumentation, namely assessing aspects of data, claims, warrant and backing. The results of the experimental class argumentation skills showed good criteria (70.82\%), whereas in the control class with sufficient criteria $(68.40 \%)$. It can be concluded that the make a match model aided by biocard affects the student's argumentation skills.
\end{abstract}

Keywords: learning outcomes, argumentation skills, make a match.

\section{PENDAHULUAN}

Belajar merupakan suatu kegiatan berproses dan unsur yang sangat penting dalam penyelenggaraan tingkatan pendidikan. Hal tersebut berarti berhasilnya 
pencapaian suatu tujuan dalam pendidikan sangat bergantung pada berhasilnya poses pembelajaran siswa baik di sekolah maupun lingkungan (Jihad dan Hadi, 2013). Pada proses belajar mengajar guru diharapkan bijaksana saat menentukan suatu model pembelajaran yang sesuai dengan kondisi di dalam kelas, sehingga akan menciptakan suasana belajar nyaman bagi siswa dan proses pembelajaran dapat berlangsung sesuai tujuan yang diharapkan. Apabila model pembelajaran yang digunakan oleh guru tepat, maka akan berdampak terhadap meningkatnya prestasi siswa, salah satunya pada hasil belajar siswa (Trianto, 2009).

Selain hasil belajar, diperlukan suatu proses pembelajaran yang dapat melatih keterampilan berpikir siswa, salah satu keterampilan berpikir yang dapat dikembangkan yaitu keterampilan berargumentasi. Keterampilan argumentasi mampu membuat siswa berpikir lebih kritis terhadap penjelasan fenomena berkaitan dengan ilmu pengetahuan alam yang terjadi di dalam kehidupan seharihari berdasarkan teori atau konsep yang ada (Osborne dalam Ginanjar, dkk., 2015). Keterampilan berargumentasi diakui sebagai faktor penting untuk keberhasilan siswa di dalam maupun di luar sekolah. Kemampuan untuk mengintegrasikan pengetahuan dan ide-ide; menggambarkan dan mengevaluasi klaim dan argumen; serta menilai alasan yang digunakan dalam argumen, khususnya terkait dengan literasi dalam bidang sains dan teknis juga sangat diperlukan oleh siswa (Frey, et al., 2015).

Berdasarkan hasil wawancara dengan guru mata pelajaran Ilmu Pengetahuan Alam, diketahui bahwa materi Klasifikasi Makhluk Hidup adalah materi yang lebih rendah nilainya jika dibandingkan dengan materi yang lain. Rendahnya hasil belajar siswa pada materi Klasifikasi Makhluk Hidup dapat dilihat melalui rata-rata nilai ulangan harian siswa yang masih belum mencapai kriteria ketuntasan yaitu 75. Siswa kesulitan dalam memahami ciri dan perbedaan antara makhluk hidup dan benda tak hidup serta terdapat banyaknya nama-nama ilmiah.

Berdasarkan hasil wawancara diperoleh informasi bahwa pada saat menyampaikan materi Klasifikasi Makhluk Hidup, guru menggunakan metode ceramah yang disertai diskusi kelompok. Pembagian kelompok diskusi 
berdasarkan tempat duduk siswa. Pada saat penyampaian materi, guru menggunakan media berupa gambar. Gambar yang ditampilkan oleh guru kurang lengkap, karena hanya memuat beberapa contoh gambar saja. Penggunaan metode ceramah memang efektif dalam mengefisienkan waktu dan guru juga telah berusaha melibatkan siswa dengan menerapkan diskusi kelompok agar siswa lebih aktif dalam mengikuti pembelajaran. Namun keterlibatan siswa pada saat diskusi kelompok masih belum maksimal, karena hanya didominasi oleh siswa tertentu, sedangkan siswa yang lain lebih mengandalkan temannya.

Apabila metode ceramah terlalu sering digunakan dapat menyebabkan kebosanan dan siswa menjadi pasif (Djamarah dan Aswan, 2013). Dalam proses belajar-mengajar di kelas, guru juga belum pernah mencoba menerapkan keterampilan berargumentasi siswa, baik secara lisan maupun tulisan, karena sebagian besar proses pembelajaran masih bersifat teacher centered. Pembelajaran Biologi dikembangkan melalui berpikir analisis agar dapat menyelesaikan masalah berkaitan dengan fenomena alam, kehidupan, dan lingkungan. Karena Biologi dikembangkan dengan kemampuan berpikir analisis, oleh karenanya guru diharapkan mampu mengembangkan keterampilan berargumentasi siswa (Depdiknas dalam Dewina, dkk., 2017).

Berdasarkan fakta yang telah diuraikan, diketahui bahwa guru perlu memfasilitasi dalam proses belajar-mengajar, sehingga dapat meningkatkan hasil belajar dan siswa dapat terlibat aktif dalam menyampaikan argumentasi. Hal tersebut sangat penting dilakukan untuk mengurangi penggunaan metode ceramah dalam proses pembelajaran, akan tetapi diharapkan lebih mengajak siswa untuk aktif dalam membangun pengetahuan. Untuk mengatasi kesulitan belajar siswa yang berdampak terhadap hasil belajar dan untuk mengembangkan keterampilan argumentasi siswa dapat diatasi melalui penggunaan model pembelajaran serta media yang bervariasi dan menarik, tentunya dalam memilih suatu model pembelajaran harus menyesuaikan dengan kriteria materi sehingga dapat mencapai tujuan pembelajaran yang diharapkan. Materi Klasifikasi Makhluk Hidup merupakan materi yang mempelajari suatu konsep sehingga untuk 
mengatasi masalah yang ada, yaitu menggunakan model pembelajaran kooperatif tipe make a match disertai biocard.

Pembelajaran kooperatif merupakan suatu pembelajaran yang mempunyai tujuan untuk meningkatkan kompetensi berpikir bagi siswa dengan berdiskusi dan berargumen kritis yang berharap bahwa pemikiran kritis siswa akan muncul otomatis (Sunhaji, 2016). Model make a match merupakan model siswa mencari pasangan kartu sambil belajar suatu konsep materi dalam suasana yang menyenangkan (Rusman, 2014). Dalam menerapkan model make a match, siswa diberikan waktu untuk mencari pasangan dari kartu soal dan kartu jawaban. Apabila siswa berhasil menemukan kartu pasangan dari jawaban dan soal, maka akan diberi poin.

Penggunaan model make a match dalam proses pembelajaran dapat melibatkan siswa sehingga menjadikan pembelajaran tidak hanya bersifat teacher centered akan tetapi juga bersifat student centered. Pembagian kelompok belajar pada siswa juga dilakukan secara heterogen sehingga dalam satu kelompok terdapat pembagian merata antara siswa yang berkemampuan tinggi, sedang, dan rendah. Selain menggunakan model pembelajaran, guru juga perlu mengembangkan media pembelajaran yang menarik dan bervariasi untuk meningkatkan hasil belajar dan keterampilan siswa, salah satunya dengan menggunakan media biocard. Biocard merupakan kartu Biologi. Biocard termasuk media visual berbentuk kartu dan berisikan gambar beserta penjelasan mengenai materi Klasifikasi Makhluk Hidup, sehingga akan memudahkan siswa dalam mempelajari materi berupa konsep. Kelebihan dari penggunaan media biocard yaitu mudah diingat, mudah dibawa, praktis, dan menyenangkan (Susilana dan Cepi, 2008).

Berdasarkan latar belakang yang telah diuraikan, maka tujuan dari penelitian adalah untuk mengetahui penerapan model make a match berbantuan biocard terhadap hasil belajar dan keterampilan argumentasi siswa pada materi Klasifikasi Makhluk Hidup kelas VII. 


\section{METODE}

Metode yang digunakan dalam penelitian adalah metode eksperimen dengan rancangan nonequivalent control group design. Populasi penelitian adalah semua siswa kelas VII yang terdiri dari VII A, VII B, dan VII C tahun ajaran 2019/2020. Sampel dalam penelitian adalah siswa kelas VII B sebagai kelas kontrol yang berjumlah 27 siswa dan VII C sebagai kelas eksperimen berjumlah 27 siswa. Teknik pengumpulan data didapat dari hasil pretest dan posttest yang diberikan pada siswa dalam bentuk pilihan ganda sebanyak 20 soal. Analisis data yang digunakan yaitu, uji normalitas dengan mengunakan uji Liliefors, uji U Mann Whitney, dan menghitung Effect Size.

Keterampilan berargumentasi siswa pada penelitian dikelompokkan berdasarkan analisis model argumentasi Toulmin. Variabel penelitian yaitu bentuk argumentasi tertulis siswa. Instrumen yang digunakan yaitu berupa bentuk pertanyaan esai. Model argumentasi Toulmin dikelompokkan menjadi 6, yang terdiri dari Data (data), Claim (klaim), Warrant (pembenaran), Backing (dukungan), Qualifier (kualifikasi), dan Rebuttall (sanggahan). Namun dalam penelitian yang dilakukan, hanya 4 aspek yang diteliti, yaitu Data, Claim, Warrant, dan Backing.

Data apabila siswa mampu menuliskan informasi apapun mengenai pernyataan yang berkaitan dengan soal yang diberikan. Claim apabila siswa menuliskan argumentasinya secara tertulis. Warrant apabila siswa menuliskan hubungan dari pernyataan yang diketahui dan informasi lain, sehingga pendapat yang dinyatakan lebih kuat lagi. Backing yaitu, siswa menjawab semua pertanyaan yang diberikan (Handayani dan Muniarti, 2015). Untuk mengetahui tingkat penguasaan berargumentasi, digunakan kriteria skor nilai seperti terlihat pada Tabel 1 (Sudjono, 2009).

Tabel 1 Kriteria Skor Nilai Tingkat Penguasaan Beragumentasi Siswa

\begin{tabular}{cc}
\hline Skor & Keterangan \\
\hline $80-100$ & Sangat Baik \\
$70-79$ & Baik \\
$60-69$ & Cukup \\
$50-59$ & Kurang \\
$0-49$ & Gagal \\
\hline
\end{tabular}




\section{HASIL DAN PEMBAHASAN}

Data hasil belajar siswa pada kelas eksperimen yang diberi penerapan model pembelajaran make a match berbantuan biocard dan kelas kontrol yang diberi perlakuan menggunakan model pembelajaran konvensional disertai gambar disajikan pada Tabel 2 berikut.

Tabel 2 Hasil Pretest dan Posttest Siswa

\begin{tabular}{ccccccc}
\hline \multirow{2}{*}{ Skor } & \multicolumn{3}{c}{ Kelas Eksperimen } & \multicolumn{3}{c}{ Kelas Kontrol } \\
\cline { 2 - 7 } & $\overline{\boldsymbol{x}}$ & SD & $\begin{array}{c}\text { Ketuntasan } \\
(\boldsymbol{\%})\end{array}$ & $\overline{\boldsymbol{x}}$ & SD & $\begin{array}{c}\text { Ketuntasan } \\
(\%)\end{array}$ \\
\hline Pretest & 9,30 & 2,21 & $3,70 \%$ & 8,63 & 2,39 & $0 \%$ \\
Posttest & 16,04 & 2,25 & $77,78 \%$ & 13,74 & 3,11 & $48,15 \%$ \\
\hline
\end{tabular}

Berdasarkan Tabel 2, terlihat bahwa hasil posttest pada kelas eksperimen lebih tinggi dibandingkan dengan kelas kontrol. Hal tersebut menunjukkan bahwa ketuntasan hasil belajar di kelas eksperimen tercapai dibandingkan kelas kontrol. Pada kelas eksperimen rata-rata skor meningkat dari 9,30 menjadi 16,04 dengan persentase ketuntasan sebesar 77,78\%. Sedangkan di kelas kontrol, skor meningkat dari 8,63 menjadi 13,74 yang mempunyai persentase ketuntasan sebesar 48,15\%. Berdasarkan uji normalitas, data posttest tidak berdistribusi normal yang selanjutnya dilakukan uji U Mann-Whitney. Berdasarkan analisis nilai posttest melalui uji U Mann-Whitney diketahui bahwa $\mathrm{Z}_{\text {hitung }}<\mathrm{Z}_{\text {tabel }}$, yaitu $2,56<-1,96$. Hal tersebut menunjukan bahwa adanya perbedaan hasil belajar antara kelas eksperimen dengan kelas kontrol.

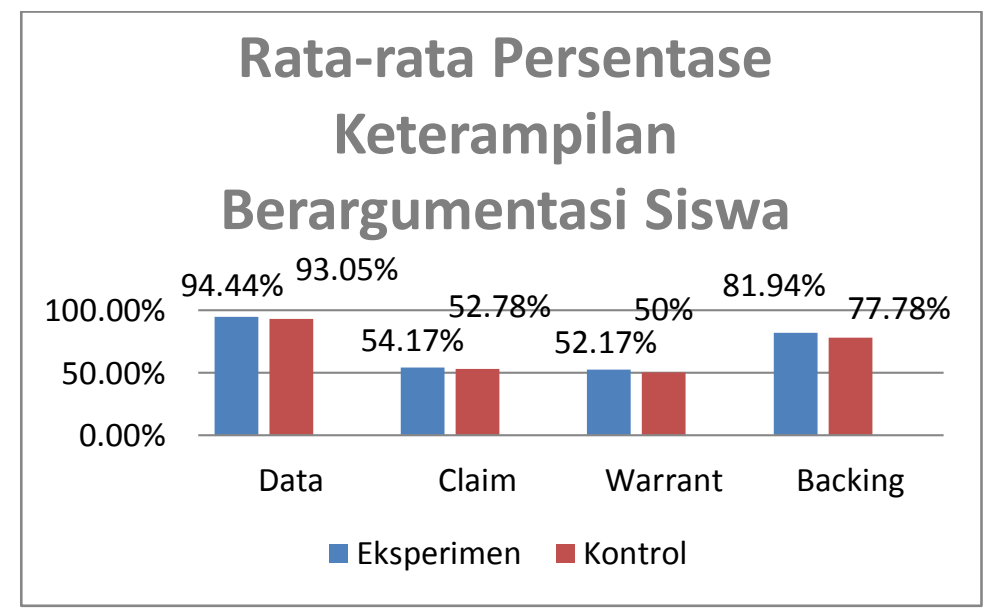

Gambar 1 Rata-Rata Persentase Keterampilan Berargumentasi Siswa 
Gambar 1 memperlihatkan bahwa di kelas eksperimen dan kelas kontrol persentase keterampilan berargumentasi tertinggi terdapat pada aspek data dengan kriteria sangat baik. Sedangkan yang terendah terdapat pada aspek warrant dengan kriteria kurang.

Tabel 3 Rata-Rata Keterampilan Argumentasi Siswa

\begin{tabular}{ccc}
\hline Kelas & Rata-Rata & Kriteria \\
\hline Eksperimen & $70,82 \%$ & Baik \\
Kontrol & $68,40 \%$ & Cukup \\
\hline
\end{tabular}

Berdasarkan Tabel 3, rata-rata keterampilan argumentasi siswa di kelas eksperimen menunjukan kriteria baik, sedangkan pada kelas kontrol dengan kriteria cukup. Hal tersebut berarti bahwa penggunaan model make a match berbantuan biocard memberikan pengaruh terhadap keterampilan argumentasi siswa secara tertulis.

Selanjutnya untuk mengetahui seberapa besar pengaruh penerapan pada kelas eksperimen dilanjutkan dengan peritungan effect size dan hasilnya menunjukkan kriteria sedang dengan nilai 0,74. Apabila nilai tersebut diubah dalam tabel kurva normal O-Z, maka diperoleh luas daerah sebesar 27,04\%. Dengan demikian terdapat perbedaan hasil belajar siswa yang diberi penerapan model make a match berbantuan biocard dengan siswa yang diberi penerapan menggunakan model konvensional berbantuan gambar.

Model pembelajaran make a match adalah model kooperatif tipe mencari pasangan dari kartu pertanyaan dan jawaban, pada tahap mencari pasangan kartu siswa lebih aktif dalam meningkatkan kemampuan berpikir. Pada saat proses bermain make a match, siswa juga diberikan kesempatan untuk bertanya dan berinteraksi dengan siswa lainnya, sehingga menjadikannya lebih aktif di dalam kelas. Penerapan model pembelajaran yang bervariasi dapat mengatasi kejenuhan siswa dalam mengikuti pembelajaran di kelas dan memiliki pengaruh terhadap tingkat pemahaman siswa. Kelebihan dari model make a match salah satunya dapat meningkatkan pemahaman (Fatmawati dan Yuliatin, 2019; Santoso, 2015) dan motivasi siswa terhadap materi yang dipelajari (Huda, 2013). 
Adanya penggunaan media biocard juga berpengaruh dalam peningkatan hasil belajar siswa. Dalam penggunaan media biocard tidak hanya guru yang menggunakan dan menjelaskan ke siswa, akan tetapi siswa juga dapat membaca serta mengamati media biocard secara langsung, sehingga pembelajaran terasa lebih menyenangkan. Media biocard memuat gambar dari setiap contoh dan memiliki penjelasan dari gambar yang ditampilkan sehingga membantu dalam memahami suatu konsep pada materi yang kurang dipahami serta memiliki tampilan yang menarik. Hal tersebut membuat siswa tertarik untuk belajar. Objek yang menarik dapat membentuk minat siswa karena adanya dorongan dan kecendrungan untuk mengetahui (Setyono, dkk., 2013).

Tabel 4 Persentase Hasil Belajar Siswa di Kelas Eksperimen dan Kontrol

\begin{tabular}{|c|c|c|c|c|}
\hline \multirow[t]{2}{*}{$\begin{array}{c}\text { Indikator } \\
\text { Pembelajaran }\end{array}$} & \multicolumn{2}{|c|}{$\begin{array}{c}\text { Rata-rata Persentase } \\
\text { Jawaban Benar } \\
\text { Persoal }\end{array}$} & \multicolumn{2}{|c|}{$\begin{array}{c}\text { Rata-rata Persentase } \\
\text { Jawaban Benar } \\
\text { Perindikator } \\
\text { Pembelajaran }\end{array}$} \\
\hline & $\begin{array}{c}\text { Eksperimen } \\
(\%)\end{array}$ & $\begin{array}{c}\text { Kontrol } \\
(\%)\end{array}$ & $\begin{array}{c}\text { Eksperimen } \\
(\%)\end{array}$ & $\begin{array}{c}\text { Kontrol } \\
(\%)\end{array}$ \\
\hline $\begin{array}{l}\text { Membedakan makhluk hidup } \\
\text { dan benda tak hidup }\end{array}$ & 92,59 & 88,89 & 92,59 & 88,89 \\
\hline \multirow{3}{*}{ Memahami ciri makhluk hidup } & 88,89 & 85,18 & \multirow{3}{*}{93,83} & \multirow{3}{*}{83,95} \\
\hline & 100 & 92,59 & & \\
\hline & 92,59 & 74,07 & & \\
\hline \multirow{2}{*}{$\begin{array}{l}\text { Memahami sistem tata nama } \\
\text { binomial }\end{array}$} & 77,78 & 66,67 & \multirow[b]{2}{*}{85,18} & \multirow[b]{2}{*}{68,52} \\
\hline & 92,59 & 70,37 & & \\
\hline \multirow{3}{*}{$\begin{array}{l}\text { Menjelaskan bagian-bagian } \\
\text { dan fungsi dari mikroskop }\end{array}$} & 85,18 & 74,07 & \multirow{3}{*}{83,95} & \multirow{3}{*}{77,78} \\
\hline & 88,89 & 81,48 & & \\
\hline & 77,78 & 77,78 & & \\
\hline \multirow{3}{*}{$\begin{array}{l}\text { Mengklasifikasikan kelompok } \\
\text { monera, protista dan fungi } \\
\text { berdasarkan ciri }\end{array}$} & 62,96 & 44,44 & \multirow{3}{*}{71,60} & \multirow{3}{*}{53,08} \\
\hline & 70,37 & 51,85 & & \\
\hline & 81,46 & 62,96 & & \\
\hline \multirow{4}{*}{$\begin{array}{l}\text { Mengidentifikasi ciri } \\
\text { tumbuhan paku, tumbuhan } \\
\text { lumut dan tumbuhan berbiji }\end{array}$} & 88,89 & 55,56 & \multirow{4}{*}{76,85} & \multirow{4}{*}{61,11} \\
\hline & 66,67 & 55,56 & & \\
\hline & 59,26 & 51,85 & & \\
\hline & 92,59 & 81,48 & & \\
\hline \multirow{4}{*}{$\begin{array}{l}\text { Mengklasifikasikan makhluk } \\
\text { hidup kedalam kelompok } \\
\text { hewan bertulang belakang dan } \\
\text { tak bertulang belakang }\end{array}$} & 74,07 & 74,07 & \multirow{4}{*}{72,22} & \multirow{4}{*}{64,81} \\
\hline & 66,67 & 59,25 & & \\
\hline & 66,67 & 48,15 & & \\
\hline & 81,48 & 77,78 & & \\
\hline \multicolumn{3}{|c|}{ Rata-Rata } & 82,32 & 71,16 \\
\hline
\end{tabular}


Berdasarkan Tabel 4, terlihat rata-rata ketercapaian siswa menjawab benar soal posttest perindikator tujuan pembelajaran, pada kelas eksperimen lebih tinggi $(82,32 \%)$ dibandingkan kelas kontrol $(71,16 \%)$. Hal tersebut berarti bahwa penggunaan model make a match berbantuan biocard memberikan pengaruh terhadap hasil belajar siswa.

Tujuan pembelajaran pertama, yaitu membedakan makhluk hidup dan benda tak hidup. Persentase ketuntasan pada kelas eksperimen lebih tinggi $(92,59 \%)$ dari kelas kontrol (88,89\%). Pada saat menjelaskan perbedaan antara makhluk hidup dan benda tak hidup pada kelas eksperimen, siswa memegang biocard yang terdapat penjelasan di dalam media tersebut dan disertai gambar. Sedangkan di kelas kontrol, siswa hanya mendengar dari penjelasan guru sehingga pada saat guru menjelaskan, siswa yang kurang mendengarkan kemungkinan besar tidak mengerti atau tidak memahami materi. Penggunaan media biocard dapat membuat pembelajaran di dalam kelas terasa lebih menyenangkan karena dapat menarik minat siswa untuk belajar sambil bermain sehingga dapat mengurangi rasa bosan pada siswa ketika mengikuti proses belajar-mengajar di kelas, serta dapat menghemat waktu pembelajaran bagi guru (Yusriana, dkk., 2017).

Tujuan pembelajaran yang kedua, yaitu memahami ciri makhluk hidup. Persentase ketuntasan pada kelas eksperimen lebih tinggi $(93,83 \%)$ dari kelas kontrol $(83,95 \%)$. Pada soal nomor 9 berupa gambar, saat menjelaskan materi di kelas eksperimen menggunakan media biocard yang berisi gambar serta penjelasan dan memuat contoh dari setiap ciri makhluk hidup, sehingga memudahkan siswa memahami contoh dari setiap ciri-ciri makhluk hidup. Di kelas eksperimen juga diberikan penerapan dengan pembelajaran make a match soal serupa sudah dimainkan pada saat mencari kartu jawaban dan kartu soal, sehingga siswa lebih mengingat materi tersebut. Sedangkan di kelas kontrol siswa hanya menerima penjelasan dari guru dan guru hanya menampilkan beberapa gambar dari contoh ciri makhluk hidup. Penggunaan dari model pembelajaran make a match dapat memperbaiki hasil belajar dan meningkatkan kualitas dalam proses pembelajaran siswa (Munir, dkk., 2018). 
Tujuan pembelajaran yang ketiga, yaitu memahami sistem tata nama binomial. Persentase ketuntasan pada kelas eksperimen lebih tinggi $(85,18 \%)$ dibandingkan kelas kontrol (68,52\%). Hal tersebut disebabkan pada kelas eksperimen yang menggunakan biocard sudah terdapat contoh yang sama seperti di soal hanya saja nama tumbuhan yang digunakan berbeda. Sedangkan pada kelas kontrol, pada saat menjelaskan guru juga menuliskan contoh di papan tulis, namun pada saat guru menerangkan siswa kurang mendengarkan, sehingga pada saat diberikan soal serupa siswa tidak memahami soal tersebut.

Tujuan pembelajaran yang keempat, yaitu menjelaskan bagian-bagian dan fungsi dari mikroskop. Persentase ketuntasan pada kelas eksperimen lebih tinggi $(83,95 \%)$ dibandingkan kelas kontrol $(77,78 \%)$. Hal tersebut dikarenakan pada soal yang diberikan, siswa diminta menunjukkan nama bagian dari mikroksop serta menyebutkan fungsinya. Pada kelas eksperimen, menggunakan media biocard yang menampilkan gambar dari miksroskop serta bagian dan fungsinya, sehingga pada saat guru telah menjelaskan namun siswa masih belum memahami, siswa masih dapat membaca kembali bagian yang belum dipahami. Guru juga memberikan penekanan berulang. Sedangkan di kelas kontrol, siswa hanya menerima penjelasan dari guru menggunakan lembar kerja siswa yang tidak berwarna, sehingga membuat siswa sulit melihat bagian gambar dengan jelas.

Tujuan pembelajaran yang kelima, yaitu mengklasifikasikan kelompok monera, protista, dan fungi berdasarkan ciri. Persentase ketuntasan pada kelas eksperimen lebih tinggi $(71,60 \%)$ dibandingkan kelas kontrol $(53,08 \%)$. Hal tersebut disebabkan di kelas eksperimen menerapkan model pembelajaran make a match. Siswa bermain menggunakan kartu dan mencari pasangan dari kartu jawaban dan kartu soal, sehingga memudahkan siswa untuk mengingat kembali konsep-konsep penting pengklasifikasian dari kelompok monera, protista, dan fungi. Sedangkan pada kelas kontrol, siswa hanya menerima penjelasan dari guru dan lembar kerja siswa yang lebih banyak penjelasan materi dibandingkan gambar sehingga membuat siswa bosan membacanya. Penerapan model pembelajaran make a match dengan bermain menggunakan kartu bergambar dapat 
meningkatkan hasil belajar dengan membuat siswa tertarik dan semangat belajar (Berlian, dkk., 2017).

Tujuan pembelajaran keenam, yaitu mengidentifikasi ciri tumbuhan paku, lumut, dan berbiji. Persentase ketuntasan siswa pada kelas eksperimen lebih tinggi $(76,85 \%)$ dibandingkan kelas kontrol $(61,11 \%)$. Hal tersebut dikarenakan pada kelas eksperimen, guru memberikan penekanan berulang pada materi yang diajarkan sehingga lebih mudah dipahami. Sedangkan pada kelas kontrol, materi disampaikan melalui penjelasan guru berbantuan media gambar. Pada saat guru menjelaskan siswa diharuskan untuk memahami materi, kemudian siswa cenderung menghapal konsep. Apabila siswa mempunyai daya ingat yang rendah, maka siswa akan keliru dalam menjawab soal. Hal tersebut terlihat saat diberikan soal yang berisi pilihan jawaban mengecohkan, siswa merasa kebingungan dalam menjawab, karena siswa masih belum menguasai konsep dengan baik. Apabila memiliki daya tarik, pengecoh dapat berfungsi bagi peserta tes yang kurang memahami suatu materi (Arikunto, 2013).

Tujuan pembelajaran ketujuh, yaitu mengklasifikasikan makhluk hidup kedalam kelompok hewan bertulang belakang dan tak bertulang belakang berdasarkan ciri. Persentase ketuntasan hasil belajar siswa pada kelas eksperimen sebesar 72,22\%, sedangkan pada kelas kontrol sebesar 64,81\%. Hal tersebut disebabkan di kelas eksperimen pembelajaran menggunakan model pembelajaran make a match yaitu bermain kartu. Make a match dapat memotivasi belajar sehingga meningkatkan hasil belajar siswa. Kelebihan dari model make a match ialah dapat meningkatkan motivasi belajar serta pemahaman siswa terhadap materi yang diajarkan (Huda, 2013). Siswa yang mempunyai motivasi tinggi dalam belajar akan lebih tertarik untuk mencari pengetahuan dan mempunyai keinginan untuk mengetahui suatu hal yang baru sehingga hal tersebut dapat berdampak pada hasil belajar siswa. Pada kelas kontrol materi disampaikan melalui penjelasan guru yang berbantuan media gambar. Pada saat mengikuti kegiatan pembelajaran di kelas, siswa kurang antusias dalam mendengarkan penjelasan materi yang disampaikan oleh guru, sehingga menyebabkan siswa merasa bosan dan kurang termotivasi dalam mengikuti proses belajar-mengajar. 
Apabila ceramah selalu digunakan dan terlalu lama dapat membosankan serta dapat membuat siswa menjadi pasif (Djamarah dan Aswan, 2013). Penggunaan media gambar yang hanya ditempel di depan kelas tidak menjangkau untuk semua siswa yang berada di dalam kelas.

Gambar 1 menunjukkan bahwa aspek data (data) di kelas kontrol dan kelas eksperimen sama-sama mempunyai kriteria sangat baik. Hal tersebut dikarenakan siswa dapat menginformasikan apa saja yang diketahui dan menuliskannya berdasarkan data atau informasi yang mereka peroleh baik itu dari media biocard di kelas eksperimen maupun lembar kerja siswa pada pada kelas kontrol. Informasi yang siswa perlukan untuk menjawab soal sebagian terdapat pada media biocard. Oleh karenanya, aspek data pada keterampilan berargumentasi tertulis siswa mendapatkan nilai tertinggi dengan kriteria sangat baik.

Aspek dukungan (backing) memiliki nilai tertinggi kedua setelah aspek data, baik di kelas eksperimen atau kelas kontrol. Pada kelas eksperimen, aspek dukungan memiliki kriteria sangat baik $(81,94 \%)$, sedangkan pada kelas kontrol memiliki kriteria baik $(77,78 \%)$. Keduanya memiliki perbedaan dikarenakan pada kelas eksperimen jumlah kelompok yang dapat menjawab benar semua soal pada LKPD lebih banyak dibandingkan kelas kontrol. Hal tersebut dikarenakan di kelas eksperimen diterapkan model make a match disertai dengan penggunaan media biocard, sedangkan di kelas kontrol hanya diberikan perlakuan dengan menerapkan model pembelajaran konvensional yaitu ceramah disertai media gambar.

Aspek klaim (claim) pada kelas eksperimen maupun kelas kontrol termasuk dalam kriteria kurang. Hal tersebut dikarenakan siswa tidak dapat menuliskan bentuk argumentasinya atau informasi yang diperoleh. Kebanyakan kelompok menuliskan jawaban berdasarkan data yang diperoleh dari media biocard dan lembar kerja yang tersedia. Keterampilan siswa dalam menuliskan bentuk argumentasinya secara tertulis masih perlu ditingkatkan lagi. Sebagian besar siswa belum terampil dalam menuliskan argumentasi ilmiah (Muslim dan Suhandi, 2012). 
Aspek pembenaran (warrant) di kelas eksperimen dan kelas kontrol memiliki kriteria kurang. Hal tersebut dikarenakan dalam menjawab soal, siswa belum dapat menuliskan informasi lain dengan informasi yang diperoleh untuk menghubungkan keduanya sehingga informasinya lebih kuat dan diterima. Beberapa kelompok hanya menuliskan jawaban terkait permasalahan sesuai dengan apa yang didapat dari data, tidak menuliskan pernyataan lain untuk menguatkan jawaban yang dituliskan. Siswa jarang menghubungkan argumen dengan bukti dan jarang menggunakan data untuk mendukung bukti ketika menjawab suatu pertanyaan (McNeill, 2011).

Hasil penelitian terlihat bahwa hasil belajar dan keterampilan berargumentasi tertulis siswa di kelas kontrol lebih rendah apabila dibandingkan dengan kelas eksperimen. Hal tersebut dikarenakan pembelajaran di kelas kontrol menggunakan model konvensional disertai dengan ceramah. Kemampuan siswa dalam berargumentasi belum optimal disebabkan pada proses belajar-mengajar yang dikembangkan jika dibandingkan memotivasi siswa dalam mengemukakan pendapat, guru lebih banyak menekankan pemberian pada materi (Firdauzi, dkk., 2019).

\section{SIMPULAN}

Berdasarkan analisis data penelitian yang telah dilakukan, maka disimpulkan: (1) Penerapan model make a match berbantuan biocard dapat meningkatkan hasil belajar pada siswa; (2) Rata-rata nilai hasil belajar siswa pada kelas eksperimen sebesar 16,04 dan pada kelas kontrol sebesar 13,74; (3) Terdapat perbedaan skor hasil belajar siswa yang diberi perlakuan menggunakan model pembelajaran make a match berbantuan media biocard dengan siswa yang diberi perlakuan model konvensional berbantuan media gambar yaitu -2,56 < 1,96; (4) Perhitungan effect size diperoleh hasil sebesar 0,74 dengan kriteria sedang dan memberikan pengaruh sebesar 27,04\%; dan (5) Model make a match berbantuan biocard memiliki pengaruh terhadap keterampilan argumentasi siswa secara tertulis yang memiliki kriteria baik pada kelas eksperimen dan kriteria cukup pada kelas kontrol. 


\section{DAFTAR PUSTAKA}

Arikunto, S. 2013. Prosedur Penelitian. Jakarta: Rineka Cipta.

Berlian, Z., Kurratul, A., \& Siti, N. 2017. Pengaruh Model Pembelajaran Kooperatif Tipe Make a Match terhadap Hasil Belajar Siswa pada Mata Pelajaran Biologi di SMP Negeri 10 Palembang. Jurnal Pendidikan, 3(1): 13-17.

Dewina, S., Ondi, S., \& Rahma, W. 2017. Pengaruh Model Pembelajaran Problem Based Learning (PBL) terhadap Kemampuan Menganalisis dan Keterampilan Berargumentasi Siswa pada Konsep Pencemaran Lingkungan di Kelas X. Jurnal Pendidikan dan Biologi, 9(2): 54-65.

Djamarah, S. B. \& Aswan, Z. 2013. Strategi Belajar Mengajar. Jakarta: Rineka Cipta.

Fatmawati, E. \& Yuliatin, R. Perbedaan Model Pembelajaran Kooperatif Tipe Teams Games Tournament dan Make a Match terhadap Hasil Belajar. Edukasi: Jurnal Pendidikan, 17(1): 27-37.

Firdauzi, F. S., Rahma, W., \& Handayani, H. 2019. Penerapan Model Pembelajaran Problem Based Learning Dipadu Metode Debat terhadap Kemampuan Berargumentasi. Jurnal Pendidikan dan Biologi, 11(1): 110 .

Frey, B. B., James, D. E., Janis, A. B., Jana, C. H., \& Marilyn, A. 2015. Development of a Test of Scientific Argumentation. Electronic Journal of Scienc e Education, 19(4): 1-18.

Ginanjar, W. S., Setiya, U., \& Muslim. 2015. Penerapan Model ArgumentDriven Inquiry dalam Pembelajaran IPA untuk Meningkatkan Kemampuan Argumentasi Ilmiah Siswa SMP. Jurnal Pengajaran MIPA, 20(1): 32-37.

Handayani, P. \& Murniati, S. M. S. 2015. Analisis Argumentasi Peserta Didik Kelas X SMA Muhammadiyah 1 Palembang dengan Menggunakan Model Argumentasi Toulmin. Jurnal Inovasi dan Pembelajaran Fisika, 2(1): 60-68.

Huda, M. 2013. Model-Model Pengajaran dan Pembelajaran. Yogyakarta: Pustaka Pelajar.

Jihad, A. \& Hadi, A. 2013. Evaluasi Pembelajaran. Yogyakarta: Pressindo.

McNeill, K. L. 2011. Elementary Student's Views of Explanation, Argumentation, and Evidence, and Their Abilities to Construct Arguments Over the School Year. Journal of Research in Science Teaching, 48(7): 793823.

Munir, M. K., Insar, D., \& Iwan. 2018. Pengaruh Model Pembelajaran Make a Match terhadap Hasil Belajar Siswa di Kelas VII SMP Yapis Manokwari. Jurnal Ilmu Pendidikan Dasar, 2(1): 120-129.

Muslim \& Suhandi, A. 2012. Pengembangan Perangkat Pembelajaran Fisika Sekolah untuk Meningkatkan Kemampuan Kognitif dan Keterampilan Berargumentasi. Jurnal Pendidikan Fisika Indonesia, 8(2): 174-183.

Rusman. 2014. Model-Model Pembelajaran. Jakarta: Rajawali Pers. 
Santoso, D. 2015. Efektivitas Motode Jigsaw dan Make a Match Meningkatkan Kualitas Belajar Arsitektur dan Organisasi Komputer. Edukasi: Jurnal Pendidikan, 13(2): 133-149.

Setyono, Y. A., Sukarmin, K., \& Daru, W. 2013. Pengembangan Media Pembelajaran Fisika Berupa Buletin dalam Bentuk Buku Saku untuk Pembelajaran Fisika Kelas VIII Materi Gaya Ditinjau dari Minat Baca Siswa. Jurnal Pendidikan Fisika, 1(1): 118-126.

Sudjono, A. 2009. Pengantar Evaluasi Pendidikan. Jakarta: Rajawali Press.

Sunhaji. 2016. Implementation of Cooperative Learning Strategy in Forming the Student about Thinking Skill of the Whole of State Islamic Senior High Schools in Purwokerto City Indonesia. International Journal of Education and Research, 4(10): 131-144.

Susilana, R. \& Cepi, R. 2008. Media Pembelajaran. Bandung: CV. Wacana Prima.

Trianto. 2009. Mendesain Pembelajaran Inovatif-Progresif. Jakarta: Kencana Pernanda Media Grub.

Yusriana, C., Syamswisna, \& Reni, M. 2017. Kelayakan Biocard sebagai Media Sub Materi Manfaat Keanekaragaman Hayati Kelas X SMA. Jurnal Pendidikan dan Pembelajaran, 6(12): 1-10. 